\title{
PENCATATAN TRANSAKSI KEUANGAN BERBASIS TEKNOLOGI BAGI GURU DI ERA REVOLUSI INDUSTRI 4.0
}

\author{
Retnoningrum Hidayah $^{1 *}$, Sukirman ${ }^{2}$, Linda Agustina ${ }^{3}$, \\ Dhini Suryandari ${ }^{4}$, Djoko Sanjoto ${ }^{5}$ \\ Jurusan Akuntansi, Fakultas Ekonomi, Universitas Negeri Semarang \\ SMP Muhammadiyah 3 Semarang \\ Penulis Korespodensi : retnoningrum.hidayah@mail.unnes.ac.id
}

\begin{abstract}
Abstrak
Revolusi industri telah merambah ke seluruh lini kehidupa termasuk pada bidang pendidikan. Oleh karena itu guru dituntut untuk mampu menggunakan teknologi dalam praktik kehidupan sehari-hari di lingkungan sekolah. Namun pada kenyataan, masih terdapat kasu-kasus di lingkungan sekolah terkait pengelolaan keuangan yang tidak tepat. Kegiatan pengabdian masyarakat ini bertujuan untuk meningkatkan kemampuan para guru dalam hal penggunaan teknologi untuk pengelolaan keuangan di lingkungan sekolah. Adapun sasaran pada pengabdian masyarakat ini adalah guruguru di SMP Muhammadiyah 3 Kota Semarang. Metode yang digunakan dalam pengabdian ini adalah pelatihan dan pendampingan tentang pencatatan transaksi keuangan dan pengggunaan aplikasi didalam pencatatan transaksi keuangan. Hasil kegiatan program pengabdian ini menunjukkan bahwa para guru i memahami penitngnya pengelolaan keungan berbasis teknologi di era revolusi industry 4.0. Lebih lanjut, adanya peningkatan kemampuan guru dalam pencatatan transaksi keuangan. Untuk selanjutnya, perlu adanya peningkatan kemampuan guru secara berkelanjutan agar mampu menghadapi perubahan zaman.
\end{abstract}

Kata kunci: pencatatan, keuangan, teknologi

\section{Pendahuluan}

Era revolusi industri 4.0 merupakan suata era dimana peran digital merajalela, pekerjaan yang semula diperuntukkan oleh manusia sekarang digantikan oleh robot, sistem maupun aplikasi lainnya (Fauzan, 2018). Keberadaan guru pun menjadi tonggak perubahan peradaban generasi. Generasi yang semula hanya berbasis manual harus segera beradaptasi menjadi generasi yang akrab dengan teknologi.

Sekolah menengah pertama merupakan jenjang sekolah yang wajib ditempuh oleh seluruh warga negara Indonesia dna menjadi jenjang pendidikan yang mampu digapai masyarakat. Lebih lanjut, berdasarkan Undang-Undang Republik Indonesia Nomor 20 Tahun 2003 tentang Sistem Pendidikan Nasional (Sisdiknas) pasal 6 ayat (1)

"Setiap warga negara yang berusia tujuh sampai dengan lima belas tahun wajib mengikuti pendidikan dasar."

Oleh karena itu, para pendidik di jenjang sekolah menengah pertama wajib memiliki kapabilitas pengetahuan yang cukup demi mencetak generasi penerus bangsa. Selanjutnya, Simamora (1997) menyatakan bahwa sumber daya manusia merupakan suatu elemen penting dalam organisai maupun entitas. Sehingga manusia merupakan asset negara. Pendidikan di jenjang sekolah menengah pertama diharapkan mampu meningkatkan kualitas manusia Indonesia.

Salah satu sekolah menengah pertama di kota Semarang adalah SMP Muhammadiyah 3. SMP ini telah berdiri sejak 1 Januari 1971 beralamatkan di jalan Jl. Tentara Pelajar 91, RT/RW 1/12, Dsn. Jomblang, Ds./Kel Jomblang, Kec. Candisari, Kota Semarang, Prov. Jawa Tengah. Tujuan pendirian SMP ini adalah untuk memenuhi kebutuhan masyarakat akan pendidikan yang memadai. Jumlah siswa SMP Muhammadiyah tercatat total 636 siswa dengan 318 berjenis kelamin lelaki dan 318 berjenis kelamin perempuan. Sedangkan untuk para pengajar, SMP Muhammaiyah 3 memiliki guru sebanyak 35 orang dengan kemampuan dibidang IPS, IPA, Bahasa dan lainnya. Secara detail data siswa dan guru dapat dilihat pada tabel 1 dan tabel 2 berikut ini 
Tabel 1. Data Siswa SMP Muhammadiyah 3

Semarang Periode 11 Agustus 2018

\begin{tabular}{llll}
\hline No & \multicolumn{1}{c}{ Nama Kriteria } & & Jumlah \\
\hline $\mathbf{1}$ & Rombongan Belajar & 18 \\
$\mathbf{2}$ & Siswa Total & 636 \\
$\mathbf{3}$ & Siswa Laki-Laki & 318 \\
$\mathbf{4}$ & Siswa Perempuan & 318 \\
$\mathbf{5}$ & Siswa Penerima PIP & 45 \\
\hline
\end{tabular}

Sumber : Direktorat Jenderal Pendidikan Dasar dan

Menengah, 2018

Tabel 2. Data Guru SMP Muhammadiyah 3

Semarang Periode 11 Agustus 2018

\begin{tabular}{lll}
\hline No & \multicolumn{1}{c}{ Nama Kriteria } & Jumlah \\
\hline $\mathbf{1}$ & Guru Total & 35 \\
$\mathbf{2}$ & Guru Kelas & 0 \\
$\mathbf{3}$ & Guru Kualifikasi Min.S1/D4 & 34 \\
$\mathbf{4}$ & Guru Sertifikat Pendidik & 9 \\
$\mathbf{5}$ & Memiliki Kepala Tenaga Administrasi & 0 \\
$\mathbf{6}$ & Memiliki Kepala Tenaga Pustakawan & 0 \\
$\mathbf{7}$ & Memiliki Kepala Tenaga & 0 \\
& Laboratorium & 1.94 \\
$\mathbf{8}$ & Rasio Guru Terhadap Kelas & 1.94 \\
\hline $\mathbf{9}$ & Rasio Guru Terhadap Rombel & \\
\hline
\end{tabular}

Sumber : Direktorat Jenderal Pendidikan Dasar dan

Menengah, 2018

Lebih lanjut, didalam sekolah ini memiliki unit usaha pra-koperasi dimana unit ini melayani kebutuhan para siswa terkait seragam, alat tulis, jajan dan lainnya. Namun kondisi yang terjadi yaitu penguruss belum begitu mahir didalam pencatatan transaksi keuangan sehingga laba dan saldo kas dari unit usaha ini sulit dideteksi. Lebih lanjut, ketidakpahaman para guru lainnya mengakibatkan kondisi ini terjadi hingga sekarang tanpa adanya solusi. Oleh karena itu meningkatkan kesejahteraan para guru melalui unit usaha ini maka perlu peningkatan kemampuan pencatatn transaksi agar pengurus unit dn seluruh guru paham tentang bagaimana pencatatan transaksi keuangan yang baik. Selain itu, guru merupakan tonggak pendidik bagi masyarakat, guru yang hebat akan menghasilkan masyarakat yang hebat pula. Dengan adanya pemahaman dari seluruh elemen sekolah terutama guru-guru maka akan mampu saling memantau unit usaha sekolah sehingga tujuan utama dapat tercapai serta dapat berkontribusi bagi masyarakat sekitar.

Berdasarkan kondisi diatas maka dapat disimpulkan kondisi di SMP muhammadiyah 3 sudah cukup mema dai untuk meningkatkan kualitas pendidikan masyarakat. Namun apabila dicermati leih lanjut maka masih perlunya peningkatan kemampuan para guru mengingat era digital 4,0 telah merambah. Oleh karena itu dalam rangka peningkatan kualitas su mber daya guru menghadapi era digital 4.0 maka tim pengabdi melakukan kegiatan pengabdian berupa peningkatan kemampuan pencatatan keuangan guru sekolah menengah pertama (SMP) Muhammadiyah 3 Semarang berbasis teknologi. Kegiatan pengabdian ini menerapkan pemanfaatan software excel dan aplikasi android dalam rangka meningkatkan kemampuasn teknologi dan keilmuan para guru.

\section{Bahan dan Metode}

Kegiatan pengabdian masyarakat ini menggunakan peralatan diantaranya:

a. Komputer dan laptop dengan aplikasi sistem excel yang telah dimodifikasi oleh tim dan dirancang khusus aga rmudah digunakan oleh para guru.

b. Handphone dengan sistem andori

Kegiatan pengabdian ini diikuti oleh guru-guru Sekolah Menengah Pertama (SMP) Muhammadiyah 3 di Kota Semarang. Adapun jumlah guru yaitu 35 orang. Akan tetapi pada saat pelaksanaan hanya terdapat 30 guru yang hadir mengikuti kegiatan hingga selesai. Kegiatan ini dilaksanakan oleh Tim Pengabdian Kepada Masyarakat Fakultas Ekonomi Universitas Negeri Semarang.

Metode pelaksanaan kegiatan ini terbagi menjadi tiga yaitu tahap persiapan, tahap pelaksanaan, dan tahap pendampingan. Pertama, tahap persiapan terdiri dari a) konsolidasi dengan kepala sekolah dan wakil kepala bidang kurikulum SMP Muhammadiyah 3 terkait kebutuhan keilmuan para guru, b) koordinasi perencanaan pelaksanaan mulai dari hari dan kebutuhan operasional lainnya. Kedua, tahap pelaksanaan yang meliputi a). penjelasan tentang pencatataan keuangan secara manual, b). penjelasan tentang pencatatatn keuangan dengan menggunakan sistem keuangan yang telah kami siapkan serta aplikasi android. Ketiga, tahapan monitoring dan evaluasi. 


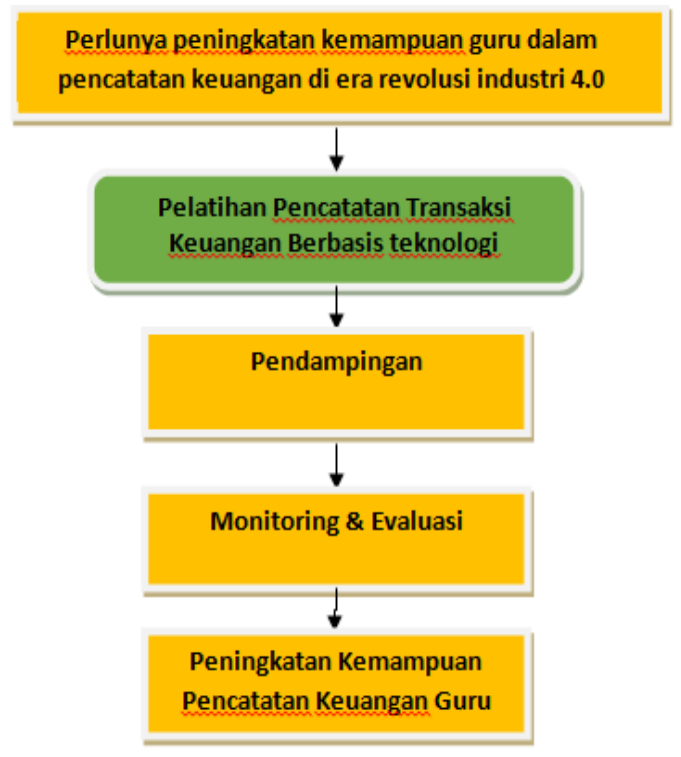

Gambar 1. Skema Pemecahan Masalah

\section{Hasil dan Pembahasan}

Guru merupakan tulang punggung bagi kecerdasan bangsa. Guru yang berkualitas akan mampu menghasilkan peserta didik yang handal. Oleh karena itu peningkatan kualitas guru di segala bidang harus dilakukan. Terlebih lagi dengan adanya era revolusi industry 4.0 yang penuh dengan tantangan. Menurut Fauzan (2018) menyatakan bahwa era revolusi industry 4.0 ini akan menyebabkan $75 \%$ pekerjaan diambil alih oleh kemampuan sains, teknologi, teknik dan matematika, internet of things (IoT), dan pembelajaran terus menerus. Pada era ini seluruh guru dituntut untuk mampu mengikuti perkembangan zaman. Oleh karena itu, peningkatan sumber daya guru harus senantiasa dilakukan. Oleh karena itu, kegiatan ini keuangan dan android.

Kegiatan ini terdiri dari tiga tahapan yaitu persiapan, pelaksanaan, dan pendampingan. Pertama, tahapan persiapan dilakukan oleh tim pengabdian dengan melakukan rapat koordinasi dengan wakil kepala sekolah dan kepala sekolah. Koordinasi ini dilakukan untuk melakukan pemetaan kebutuhan keilmuaan para guru. Setelah itu, dilakukan penyusunan kerangka pelaksanaan yang terdiri dari penentuan hari pelaksanaan dan materi pengabdian.

Kedua, tahap pelaksanaan dilakukan dengan dua tahapan yaitu teori dan praktik. Pada saat tahap teori, para guru diberikan materi tentang pencatatan keuangan sederhana mulai dari transaksi pendapatan, pembelian dan lainnya. Para guru mengikuti pemaparan teori secara tertib dan antusias. Hal ini terbukti dengan adanya pertanyaan-pertanyaan kritis yang dilontarkan para guru kepada tim pengabdi. Para guru terlihat sangat bersemangat untuk mengikuti pelatihan. Selanjutnya, tahapan praktik yaitu tim pengabdi mengajarkan pencatatan dengan menggunakan android handphone. Selanjutnya, tim pengabdi mempersilahkan para guru untuk praktik menggunakan sistem keuangan yang telah tim pengabdi buat dengan menggunakan excel. Penggunaan android handphone untuk pencatatan hanya diperkenalkan sedikit dikarenakan android memiliki banyak kelemahan yaitu lebih rentan akan eror dan risiko hilang data yang tinggi.

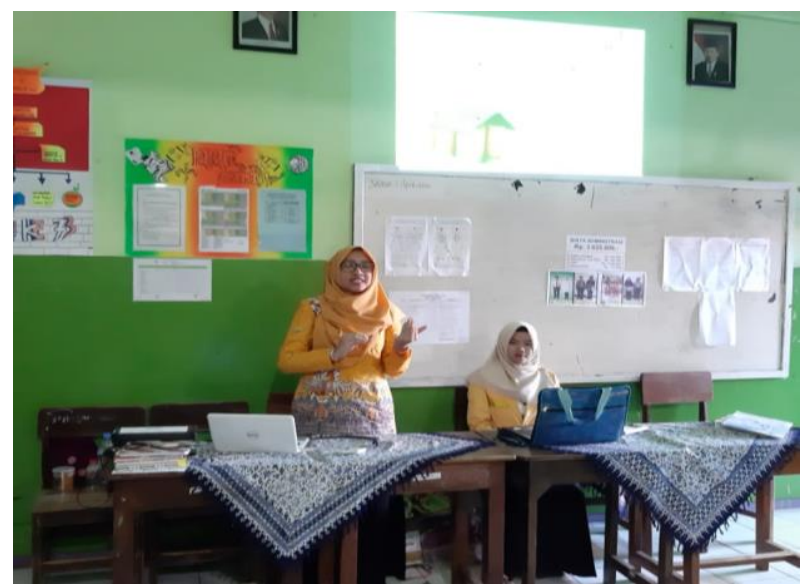

Gambar 2. Pemaparan Materi

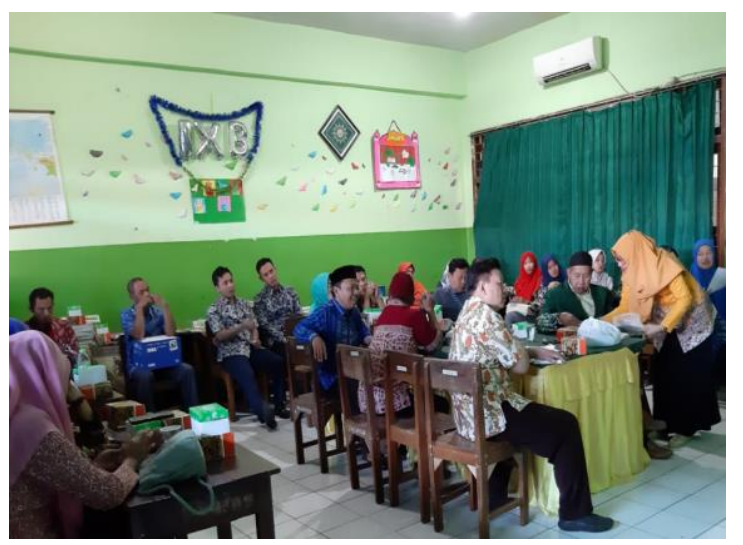

Gambar 3. Mendampingi Peserta

Ketiga, tahap monitoring dan evaluasi. Tahapan ini merupakan tahapan pendampingan dimana Tim Pengabdian menyerahkan sistem keuangan yang telah tim persiapkan secara gratis kepada pihak SMP Muhammadiyah 3 melalui kepala sekolah. Selanjutnya, tahapan monitoring 
dan evaluasi dilaksanakn, dimana pihak sekolah diperkenankan untuk berkomunikasi dengan tim terkait kendala-kendala yang ditemui selama penerapan ilmu atau sistem tersebut dan tim pengabdian memberikan solusi terkait kendala yang dihadapi

Berdasarkan kegiatan yang telah dilakukan maka para guru telah mampu melakukan pencatatan transaksi keuangan dengan menggunakan aplikasi sistem excel dan android. Lebih lanjut, para guru mampu mengikuti perkembangan zaman dimana teknologi merajalela diberbagai aspek kehidupan.

\section{Kesimpulan}

Kegiatan peningkatan kualitas keilmuan para guru di bidang pencatatan keuangan berbasis teknologi telah berjalan dengan lancar. Lebih lanjut, kegiatan ini telah mampu menghasilkan suatu sistem pencatatan keuangan yang dapat digunakan oleh para guru didalam memenuhi kebutuhan keilmuan mereka. Selain itu, guru-guru memperoleh tambahan ilmu terkait penggunaan teknologi dalam pencatatan transaksi keuangan. Untuk selanjutnya, kegiatan pengabdian yang terkait peningkatan kualitas guru harus terus dilakukan agar mampu meningkatkan derajat kecerdasan bangsa.

\section{Ucapan Terima Kasih}

Terimakasih kepada Fakultas Ekonomi Universitas Negeri Semarang (UNNES) yang telah memberikan dukungan dana sehingga kegiatan pengabdian masyarakat berjalan dengan lancar.

\section{Daftar Pustaka}

Direktorat Jenderal Pendidikan Dasar dan Menengah. 2018. Data Guru SMP Muhammadiyah 3 Semarang. Diakses pada tanggal 14 Februari 2019.

Direktorat Jenderal Pendidikan Dasar dan Menengah. 2018. Data Siswa SMP Muhammadiyah 3 Semarang. Diakses pada tanggal 14 Februari 2019.

Fauzan, Rahman. 2018. Karakteristik Model Dan Analisa Peluang Tantangan Industri 4.0.Jurnal Teknik Informatika Politeknik Hasnur, Volume 04, Nomor 1, Edisi April 2018

Simamora, Henry. (1997). Manajemen Sumber Daya Manusia. STIE YKPN. Yogyakarta.

Undang-Undang Republik Indonesia Nomor 20 Tahun 2003 tentang Sistem Pendidikan Nasional. Diakses pada 7 Agustus 2019 pada https://kelembagaan.ristekdikti.go.id/wpcontent/uploads/2016/08/UU_no_20_th_2003.pd $\mathrm{f}$ 